\title{
SYSTEMIC IMMUNE-INFLAMMATION INDEX (SII) AND NEUTROPHIL TO LYMPHOCYTE RATIO (NLR) ARE USEFUL MARKERS FOR ASSESSING EFFECTS OF ANTI-INFLAMMATORY DIET IN PATIENTS BEFORE CORONARY ARTERY BYPASS GRAFTING
}

\author{
Patrycja Szymanska ${ }^{1}$, Marcin Rozalski ${ }^{1}$, Miroslaw Wilczynski , Jacek Golanski ${ }^{1}$ \\ ${ }^{1}$ Department of Haemostasis and Haemostatic Disorders, Faculty of Biomedical Sciences, \\ Medical University of Lodz, Lodz, Poland \\ ${ }^{2}$ Department of Cardiac Surgery, Faculty of Cardiology and Cardiac Surgery, \\ Medical University of Lodz, Lodz, Poland
}

\begin{abstract}
Background. One of the risk factors responsible for coronary artery disease (CAD) is an inadequate diet that is frequently deficient in anti-inflammatory components, such as polyphenols and omega-3 fatty acids. The neutrophil to lymphocyte ratio (NLR) and the systemic immune-inflammation index (SII) are inflammatory markers that may reflect a diet's antiinflammatory potential.

Objective. The aim of this study was to evaluate the effects that CAD patients' nutrition patterns have on NLR and SII. Material and methods. A retrospective study assessed the dietary habits and inflammatory marker levels in patients with advanced CAD before they underwent coronary artery bypass grafting (CABG) $(n=101)$. Patients were divided into subgroups based on their NLR and SII levels.

Results. Subgroups with lower NLR and SII levels had consumed significantly more eicosapentaenoic acid (EPA) and docosahexaenoic acid (DHA) $(\mathrm{p}=0.02)$. The group with a lower ratio of omega-6 to omega-3 fatty acids $(<4: 1)$ also had lower NLR and SII levels ( $\mathrm{p}=0.007$ and $\mathrm{p}=0.01$, respectively). Statistically significant negative correlations were found between EPA and DHA, as well as omega-3 intake, and both NLR and SII values. No statistically significant differences were found between the subgroups with lower and higher NLR and SII values for polyphenol intakes.

Conclusions. Inflammatory markers such as NLR and SII may reflect an anti-inflammatory diet consumed by cardiac patients. A simultaneous assessment of dietary habits and inflammatory parameters is beneficial in the possible prevention of adverse cardiovascular incidents after CABG. There is also a need to establish reference values for SII and NLR.
\end{abstract}

Keywords: inflammatory marker, anti-inflammatory diet, omega-3, cardiovascular disease, NLR, SII

\section{STRESZCZENIE}

Wprowadzenie. Jednym z czynników ryzyka choroby wieńcowej jest nieodpowiednia dieta, często uboga w składniki o działaniu przeciwzapalnym, takie jak polifenole i kwasy tłuszczowe omega-3. Stosunek liczby neutrofilów do limfocytów (NLR) oraz wskaźnik ogólnoustrojowej reakcji immunologiczno-zapalnej (SII) są markerami stanu zapalnego, które mogą odzwierciedlać potencjał przeciwzapalny diety.

Cel badań. Celem pracy była ocena wpływu sposobu żywienia pacjentów z chorobą wieńcową na poziom NLR i SII.

Material i metody. W retrospektywnym badaniu oceniono sposób odżywiania oraz poziom markerów stanu zapalnego u pacjentów z zaawansowaną chorobą wieńcową przed poddaniem ich zabiegowi pomostowania aortalno-wieńcowego (CABG) (n=101). Pacjentów podzielono na podgrupy w zależności od poziomów NLR i SII.

Wyniki. Podgrupy z niższym poziomem NLR i SII spożywały istotnie więcej kwasu eikozapentaenowego (EPA) i dokozaheksaenowego (DHA) ( $\mathrm{p}=0,02)$. Grupa z niższym stosunkiem kwasów tłuszczowych omega-6 do omega-3 ( $<4: 1)$ miała również niższe poziomy NLR i SII (odpowiednio $\mathrm{p}=0,007 \mathrm{i} \mathrm{p}=0,01$ ). Stwierdzono istotne statystycznie ujemne korelacje pomiędzy EPA i DHA oraz spożyciem kwasów omega-3 a wartościami NLR i SII. Nie wykazano istotnych statystycznie różnic w spożyciu polifenoli pomiędzy podgrupami o niższych i wyższych wartościach NLR i SII.

Wnioski. Markery zapalne, takie jak NLR i SII, mogą odzwierciedlać dietę przeciwzapalną stosowaną przez pacjentów kardiochirurgicznych. Jednoczesna ocena sposobu żywienia i parametrów stanu zapalnego jest korzystna w ewentualnej

Funding statement: The study was supported by a grant from the Medical University of Lodz, Poland (No. 502-03/6-020-01/502-64- 128-18).

Corresponding author: Patrycja Szymańska, Department of Haemostasis and Haemostatic Disorders, Faculty of Biomedical Sciences, Medical University of Lodz, 6/8 Mazowiecka Str., 92-215 Lodz, Poland, e-mail: patrycja.szymanska@umed.lodz.pl; Phone: +48 422725720

(C) Copyright by the National Institute of Public Health NIH - National Research Institute 
prewencji niekorzystnych incydentów sercowo-naczyniowych po CABG. Istnieje również potrzeba ustalenia wartości referencyjnych dla SII i NLR.

Słowa kluczowe: marker stanu zapalnego, dieta przeciwzapalna, omega-3, choroby sercowo-naczyniowe, NLR, SII

\section{INTRODUCTION}

Many dietary compounds have been shown to have beneficial effects on atherosclerotic cardiovascular disease (CVD) risk factors [21]. One of these, polyunsaturated fatty acids (PUFAs), has been reported to improve inflammatory markers and common CVD risk factors [17, 28]. Inflammatory markers are essential in determining which group of patients has a higher risk of developing CVD and a worse prognosis following diagnosis $[10,12]$. A traditional and well-known biomarker is C-reactive protein (CRP), formed in the liver in response to proinflammatory interleukin-6 (IL-6) [24]. A CRP level above $3.0 \mathrm{mg} / \mathrm{dL}$ is associated with a high risk of CVD [20].

The neutrophil to lymphocyte ratio (NLR) is an increasingly used inflammatory biomarker that was originally associated with cancer and now also with CVD [6], and recently as a prognostic marker in COVID-19 patients [22]. Due to its low cost and ease of calculation, it could complement blood morphology and constitute a parameter for routine diagnostics [13]. NLR was also reported to be correlated with a risk of rehospitalisation and higher long-term mortality due to recurrent cardiovascular events in patients after cardiac surgery [12].

The systemic immune-inflammation index (SII) has been recently becoming more popular [29]. The index's score is obtained by multiplying the values of neutrophils and platelets and then dividing by the number of lymphocytes. The SII enables the identification of patients that have a poor prognosis following coronary artery bypass grafting (CABG) [5]. Compared to common risk factors, SII has been found to be more effective in predicting cardiac events in patients with coronary artery disease (CAD) and after surgery $[5,32]$.

In addition to inflammation, nutrition is also important in the development of CVD [4]. Plant polyphenols, as well as omega-3 polyunsaturated fatty acids are dietary components that have primarily antioxidant, anti-inflammatory and anticoagulation properties, thus having beneficial effects on the organism $[3,9,16]$. It is also worth taking heed of the properratio of omega-6 to omega-3 fatty acids-it should be about 4:1. When consumed in excess, omega- 6 fatty acids exhibit pro-inflammatory properties compared to the anti-inflammatory omega-3. An imbalance in the ratio, caused by inadequate dietary consumption, can also affect inflammatory parameters [7].
The aim of this study was to evaluate the nutritional patterns of patients with CAD before their planned CABG, taking particular account of their intake of polyphenols and fatty acids. We analysed also the effects of diet on two inflammatory markers: NLR and SII. We found that the group of patients that had lower NLR and SII levels had a higher dietary intake of plant polyphenols and anti-inflammatory fatty acids. Furthermore, decreased values of these inflammatory markers were observed in patients with lower omega-6 to omega-3 fatty acid ratios.

\section{MATERIALS AND METHODS}

\section{Patients}

Initially, the study recruited a total of 110 patients with CAD who were before planned CABG. All CABG procedures were performed at the Department of Cardiac Surgery, Faculty of Cardiology and Cardiac Surgery, Medical University of Lodz (Poland). All the patients enrolled in the study presented with complex coronary lesions including left main disease, multiplevessel disease or a coronary anatomy that was not amenable to percutaneous coronary intervention (PCI), which was reflected by a SYNTAX Score $>22$ points (intermediate and high risk).

The exclusion criteria were: history of intracranial disorders (including stroke), renal dysfunction $\left(\mathrm{eGFR}<60 \mathrm{~mL} / \mathrm{min} / 1.73 \mathrm{~m}^{2}\right.$ ), primary and metastatic brain tumours and a history of head trauma, and major surgery or high level trauma within the previous 6 weeks. An active inflammatory state was detected when CRP $>10.0 \mathrm{mg} / \mathrm{dl}$, thrombocytopenia was defined as less than $100 \times 10^{9} \mathrm{PLT} / \mathrm{L}$, anticoagulation with INR $\geq 1.5$. The dietary criteria excluded persons following an alternative diet (e.g. rigorous low-calorie/ vegetarian/elimination diets) and those with a daily calorie intake $<1000 \mathrm{kcal}$ or $>5000 \mathrm{kcal}$.

Finally, after applying the above criteria, 101 patients were included in the study. The retrospective analysis used data collected from December 2016 to June 2019. The characteristics of the group $(n=101)$ were: female sex: 5 patients $(5.0 \%)$ and male sex: 96 patients $(95.0 \%)$; age: $65.1 \pm 8.5$ years; BMI (body mass index) $28.2 \pm 4.8 \mathrm{~kg} / \mathrm{m}^{2}$; hypertension: 82 (81.2\%); dyslipidaemia: 95 (94.1\%); peripheral artery disease: 6 (5.9\%); EuroSCORE: $5.6 \pm 2.0$ points. All the patients were on aspirin till the day of their operation. A complete set of all clinical and laboratory data was gathered for the study group. 


\section{Laboratory results}

To assess the CRP level, a Modular Analytics EVO Cobas 6000 analyser (Roche, Basel, Switzerland) was used to carry out the Tina-quant C-Reactive Protein Gen. 3 immunoturbidimetric test. Blood count analysis used a Sysmex XE-2100 analyser (Sysmex Corporation, Kobe, Kansai, Japan). Complete blood morphology results were used to calculate the SII (immune-inflammation index - multiplying the values of neutrophils and platelets and then dividing by the number of lymphocytes) and NLR (neutrophil/ lymphocyte ratio) values.

\section{Dietary assessment}

A validated 125 -item food frequency questionnaire (FFQ) was used to assess the energy intake, as well as the intake of polyphenols and fatty acids [25]. The questionnaire is characterized by satisfactory repeatability and it can be assumed that it is a reliable tool for assessing the diet, as well as the intake of particular food components during the previous year.

Based on the patients' declarations, it was assumed that the frequency of consumption of the products described was constant over the year and the daily intake could be calculated according to this frequency. To estimate the daily intake from the responses, frequency conversion factors presented as times/day were used (numerical values were given in brackets for each frequency).

Respondents indicated how frequently they had consumed products, choosing one of the possible options: never ( 0 times/day), several times a year (0.02 times/day), once a month (0.03 times/day), 2-3 times a month (0.08 times/day), once a week (0.143 times/ day), twice a week (0.286 times/day), 3-4 times a week (0.5 times/day), 5-6 times a week (0.786 times/day), or every day (1 times/day). They also estimated the size of portions by choosing respectively how many glasses, pieces, slices, tablespoons or teaspoons they had consumed. For each food product, weight (expressed in grams) was assigned according to the standard portions used. The collected data was entered into a previously prepared calculation sheet, which contained data on the polyphenol and fatty acid amounts in the analysed products (per serving of the product). The content of polyphenols in the diet was calculated based on the Phenol-Explorer base, which includes information on the content of phenolic compounds (such as total polyphenols, flavonoids, phenolic acids, flavan-3-ols, lignans, and stilbenes) in plant origin products [25]. Dietary fat content (such as saturated, monounsaturated and polyunsaturated fatty acids; cholesterol; omega-3 and omega- 6 fatty acids; EPA and DHA) was calculated using the Aliant dietary program (Anmarsoft, Poland).

\section{Statistical analysis}

A statistical analysis was performed using Statistica 13.1 software (Statsoft, Poland). The normality of the distribution of the analysed variables was assessed using the Shapiro-Wilk test. Descriptive statistics were used to characterize the parameters. Mean $( \pm \mathrm{SD})$ was used to describe normal variables, while the median (Q1-Q3) was used for variables deviating from the normal distribution. Student's t-test was used to analyse the significance of differences between groups for variables with normal distribution. Analysis of variables whose distribution differed from the normal was performed using the U Mann-Whitney test. The correlation between the studied variables was analysed using Spearman's rank correlation coefficient. Cohen's kappa coefficient was used to assess the agreement of the parameters under study. The differences in the analysed variables were considered to be statistically significant if the $\mathrm{p}$-value was $<0.05$.

\section{Ethics}

All patients were informed about the detailed purpose of the study and then gave their voluntary written consent to participate. The study was approved by the Local Bioethics Committee (RNN/24/17/KE).

\section{RESULTS}

Our study calculated the inflammatory markers of patients before their planned CABG. Table 1 shows the detailed characteristics of the levels of the analysed inflammatory markers (SII and NLR) in the studied group of cardiac surgery patients $(\mathrm{n}=101)$.

In the next step, the patients $(n=101)$ were divided into two subgroups based on the median SII value: 1) with lower SII $(n=50)$ and 2) with higher SII $(n=51)$. The cut-off value was the median in all patients, SII $=430.2$. The distribution of estimated

Table 1. Characteristic of inflammatory parameters (SII and NLR) in patients with advanced CAD ( $\mathrm{n}=101)$

\begin{tabular}{|c|c|c|c|c|c|c|c|}
\hline $\begin{array}{c}\text { Inflammatory } \\
\text { marker }\end{array}$ & Mean & SD & Median & Q1 & Q3 & Min & Max \\
\hline SII & 502.2 & 312.0 & 430.2 & 342.9 & 539.8 & 151.8 & 2330.2 \\
\hline NLR & 2.42 & 1.08 & 2.15 & 1.75 & 2.81 & 1.03 & 8.46 \\
\hline
\end{tabular}

NLR - neutrophil to lymphocyte ratio; SII - systemic immune-inflammation index; SD - standard deviation; Q1- lower quartile; Q3 - upper quartile 
daily dietary intake of polyphenols, including the differences between the group with lower and higher SII is presented in Table 2 . There were no statistically significant differences in polyphenol intake between groups with higher and lower SII values. There was also no statistically significant correlation between this inflammatory marker and the dietary content of polyphenol compounds.

Table 3 shows the characteristics of the estimated daily dietary intake of fatty acids, taking into account the different value of the SII parameter. Statistically significant differences were found between the groups with higher and lower SII in the intake of EPA and DHA, as well as between the ratio of omega- 6 to omega-3 fatty acids. The intake of omega-3 fatty acids in the studied groups was on the verge of statistical significance. Moreover, a statistically significant correlation was noted between SII and the intake of omeg $a-3$ fatty acids $(\mathrm{r}=-0.24, \mathrm{p}=0.01)$, EPA and DHA acids $(r=-0.28, p=0.005)$, as well as for the ratio of omega -6 to omega-3 fatty acids $(r=0.26, p=0.008)$.

Subsequently, patients $(\mathrm{n}=101)$ were divided into two subgroups based on the median NLR value: 1) with lower NLR ( $n=51)$ and 2) with higher NLR $(n=50)$. The cut-off value was the median for all patients, NLR=2.15.

Table 4 presents the estimated daily intakes of polyphenols according to the differences between the group with lower and higher NLR values. An analysis of the levels of polyphenol consumption between

Table 2. Comparison of estimated daily dietary intake of polyphenols based on SII in patients with advanced CAD

\begin{tabular}{|c|c|c|c|c|}
\hline & Total $(\mathrm{n}=101)$ & Lower SII $(\mathrm{n}=50)$ & Higher SII $(\mathrm{n}=51)$ & $\mathrm{p}$ \\
\hline Polyphenols (mg) & $\begin{array}{c}1780 \\
(1460-2319)\end{array}$ & $\begin{array}{c}1805 \\
(1460-2533)\end{array}$ & $\begin{array}{c}1666 \\
(1448-2208)\end{array}$ & $\mathrm{p}=0.41$ \\
\hline Flavonoids (mg) & $\begin{array}{c}855 \\
(645-1135)\end{array}$ & $\begin{array}{c}866 \\
(581-1164)\end{array}$ & $\begin{array}{c}846 \\
(656-1080)\end{array}$ & $\mathrm{p}=0.88$ \\
\hline Flavan-3-ols (mg) & $\begin{array}{c}513 \\
(370-630)\end{array}$ & $\begin{array}{c}519 \\
(331-670)\end{array}$ & $\mathrm{p}=0.99$ \\
\hline Phenolic acids (mg) & $\begin{array}{c}(389-629) \\
(290-586)\end{array}$ & $\begin{array}{c}439 \\
(298-715)\end{array}$ & $\mathrm{p}=0.38$ \\
\hline Lignans (mg) & $\begin{array}{c}20.88 \\
(14.46-30.43)\end{array}$ & $\begin{array}{c}20.32 \\
(13.26-28.22)\end{array}$ & $\begin{array}{c}23.56 \\
(14.45-33.56)\end{array}$ & $\mathrm{p}=0.22$ \\
\hline Stilbenes (mg) & $\begin{array}{c}0.14 \\
(0.05-1.07)\end{array}$ & $\begin{array}{c}0.15 \\
(0.04-0.96)\end{array}$ & $\mathrm{p}=0.67$ \\
\hline
\end{tabular}

Results are presented as median (Q1-Q3). SII - systemic immune-inflammation index. Mann-Whitney U test was used to assess the significance of differences

Table 3. Comparison of estimated daily dietary intake of fatty acids based on SII in patients with advanced CAD

\begin{tabular}{|c|c|c|c|c|}
\hline & Total $(n=101)$ & Lower SII $(\mathrm{n}=50)$ & Higher SII $(n=51)$ & $\mathrm{p}$ \\
\hline Saturated fatty acids (g) & $\begin{array}{c}32.64 \\
(23.99-42.73) \\
\end{array}$ & $\begin{array}{c}32.32 \\
(25.09-40.97) \\
\end{array}$ & $\begin{array}{c}33.59 \\
(23.75-44.84) \\
\end{array}$ & $\mathrm{p}=0.77$ \\
\hline Monounsaturated fatty acids (g) & $\begin{array}{c}44.51 \\
(31.77-56.11)\end{array}$ & $\begin{array}{c}41.19 \\
(32.33-53.36)\end{array}$ & $\begin{array}{c}46.50 \\
(30.67-59.31)\end{array}$ & $\mathrm{p}=0.48$ \\
\hline Polyunsaturated fatty acids (g) & $\begin{array}{c}21.25 \\
(15.09-28.17) \\
\end{array}$ & $\begin{array}{c}20.88 \\
(18.24-26.54) \\
\end{array}$ & $\begin{array}{c}21.89 \\
(14.07-29.97) \\
\end{array}$ & $\mathrm{p}=0.86$ \\
\hline EPA+DHA (g) & $\begin{array}{c}0.72 \\
(0.40-1.12)\end{array}$ & $\begin{array}{c}0.88 \\
(0.49-1.53) \\
\end{array}$ & $\begin{array}{c}0.57 \\
(0.40-0.81) \\
\end{array}$ & $\mathrm{p}=0.02$ \\
\hline Omega-3 fatty acids (g) & $\begin{array}{c}4.13 \\
(3.03-6.13) \\
\end{array}$ & $\begin{array}{c}4.67 \\
(3.49-6.68) \\
\end{array}$ & $\begin{array}{c}3.75 \\
(2.58-5.73) \\
\end{array}$ & $\mathrm{p}=0.05$ \\
\hline Omega-6 fatty acids (g) & $\begin{array}{c}16.52 \\
(12.10-21.17)\end{array}$ & $\begin{array}{c}16.24 \\
(12.73-20.32) \\
\end{array}$ & $\begin{array}{c}16.77 \\
(10.90-23.22) \\
\end{array}$ & $\mathrm{p}=0.97$ \\
\hline Omega-6/omega-3 ratio & $\begin{array}{c}3.62 \\
(2.97-5.02) \\
\end{array}$ & $\begin{array}{c}3.33 \\
(2.36-4.87) \\
\end{array}$ & $\begin{array}{c}4.07 \\
(3.36-5.29) \\
\end{array}$ & $\mathrm{p}=0.01$ \\
\hline Cholesterol (mg) & $\begin{array}{c}342.66 \\
(278.95-441.67)\end{array}$ & $\begin{array}{c}327.83 \\
(279.50-416.75)\end{array}$ & $\begin{array}{c}349.04 \\
(274.22-474.33)\end{array}$ & $\mathrm{p}=0.75$ \\
\hline
\end{tabular}

Results are presented as median (Q1-Q3). SII - systemic immune-inflammation index; EPA - eicosapentaenoic acid, DHA - docosahexaenoic acid. Mann-Whitney U test was used to assess the significance of differences. 
patients with lower and higher NLR levels showed no statistically significant differences. Furthermore, there was no statistically significant correlation between these variables.

The differences in daily dietary fatty acid intake between groups with lower and higher NLR levels are shown in Table 5. The group with lower and higher NLR showed statistically significant differences in the intake of EPA and DHA acids and the ratio of omega-6 to omega-3. A statistically significant correlation was found between the NLR parameter and the amount of omega-3 fatty acids consumed per day $(r=-0.21$, $\mathrm{p}=0.04)$, DHA and EPA acids $(\mathrm{r}=-0.22, \mathrm{p}=0.03)$ and also the ratio of omega- 6 to omega-3 fatty acids $(r=0.27, p=0.005)$.

Due to the potential importance of the omega-6 to omega-3 fatty acids ratio, an analysis was made of the effect that levels of inflammatory markers (SII and NLR) had on this parameter. Patients $(n=101)$ were divided into two subgroups: 1) lower ratio of omega- 6 to omega-3 fatty acids $(\mathrm{n}=51)$ and 2$)$ higher ratio of omega- 6 to omega -3 fatty acids $(\mathrm{n}=50)$. The cut-off value was the median for all patients of the omega- 6 to omega -3 ratio $=4: 1$.

The group with a lower ratio of omega-6 to omega-3 exhibited lower levels of SII and NLR (Figure 1).

Table 4. Comparison of estimated daily dietary intake of polyphenols based on NLR in patients with advanced CAD

\begin{tabular}{|c|c|c|c|c|}
\hline & Total & Lower NLR (n=51) & $\begin{array}{c}\text { Higher NLR } \\
(\mathrm{n}=50)\end{array}$ & $\mathrm{p}$ \\
\hline Polyphenols (mg) & $\begin{array}{c}1780 \\
(1460-2319)\end{array}$ & $\begin{array}{c}1811 \\
(1506-2526)\end{array}$ & $\begin{array}{c}1674 \\
(1385-2209)\end{array}$ & $\mathrm{p}=0.24$ \\
\hline Flavonoids (mg) & $\begin{array}{c}855 \\
(645-1135)\end{array}$ & $\begin{array}{c}883 \\
(632-1164)\end{array}$ & $\begin{array}{c}850 \\
(654-1081)\end{array}$ & $\mathrm{p}=0.87$ \\
\hline Flavan-3-ols (mg) & $\begin{array}{c}513 \\
(370-630)\end{array}$ & $\begin{array}{c}514 \\
(340-671)\end{array}$ & $\begin{array}{c}501 \\
(398-630)\end{array}$ & $\mathrm{p}=0.92$ \\
\hline Phenolic acids (mg) & $\begin{array}{c}442 \\
(290-586)\end{array}$ & $\begin{array}{c}416 \\
(298-715)\end{array}$ & $\begin{array}{c}19.75 \\
(12.99-30.43)\end{array}$ & $\mathrm{p}=0.43$ \\
\hline Lignans (mg) & $\begin{array}{c}20.88 \\
(14.46-30.43)\end{array}$ & $\begin{array}{c}21.33 \\
(17.02-30.74)\end{array}$ & $\begin{array}{c}0.20 \\
(0.05-1.10)\end{array}$ & $\mathrm{p}=0.30$ \\
\hline
\end{tabular}

Results are presented as median (Q1-Q3). NLR - neutrophil to lymphocyte ratio. Mann-Whitney U test was used to assess the significance of differences.

Table 5. Comparison of estimated daily dietary intake of fatty acids based on NLR in patients with advanced CAD

\begin{tabular}{|c|c|c|c|c|}
\hline & Total $(n=101)$ & Lower NLR $(\mathrm{n}=51)$ & $\begin{array}{l}\text { Higher NLR } \\
\quad(n=50)\end{array}$ & $\mathrm{p}$ \\
\hline Saturated fatty acids (g) & $\begin{array}{c}32.64 \\
(23.99-42.73) \\
\end{array}$ & $\begin{array}{c}32.32 \\
(24.25-41.39) \\
\end{array}$ & $\begin{array}{c}33.08 \\
(23.95-43.59) \\
\end{array}$ & $\mathrm{p}=0.88$ \\
\hline Monounsaturated fatty acids (g) & $\begin{array}{c}44.51 \\
(31.77-56.11)\end{array}$ & $\begin{array}{c}40.11 \\
(31.77-54.77)\end{array}$ & $\begin{array}{c}46.32 \\
(31.77-58.37)\end{array}$ & $\mathrm{p}=0.40$ \\
\hline Polyunsaturated fatty acids (g) & $\begin{array}{c}21.25 \\
(15.09-28.17)\end{array}$ & $\begin{array}{c}20.10 \\
(16.31-26.54)\end{array}$ & $\begin{array}{c}22.60 \\
(14.80-29.35)\end{array}$ & $\mathrm{p}=0.55$ \\
\hline EPA+DHA (g) & $\begin{array}{c}0.72 \\
(0.40-1.12) \\
\end{array}$ & $\begin{array}{c}0.84 \\
(0.50-1.46) \\
\end{array}$ & $\begin{array}{c}0.56 \\
(0.39-0.81) \\
\end{array}$ & $\mathrm{p}=0.02$ \\
\hline Omega-3 fatty acids (g) & $\begin{array}{c}4.13 \\
(3.03-6.13) \\
\end{array}$ & $\begin{array}{c}4.52 \\
(3.25-6.84) \\
\end{array}$ & $\begin{array}{c}3.96 \\
(2.60-5.52) \\
\end{array}$ & $\mathrm{p}=0.08$ \\
\hline Omega-6 fatty acids (g) & $\begin{array}{c}16.52 \\
(12.10-21.17) \\
\end{array}$ & $\begin{array}{c}15.88 \\
(12.10-20.09) \\
\end{array}$ & $\begin{array}{c}17.34 \\
(11.66-23.51) \\
\end{array}$ & $\mathrm{p}=0.28$ \\
\hline Omega-6/omega-3 ratio & $\begin{array}{c}3.62 \\
(2.97-5.02)\end{array}$ & $\begin{array}{c}3.27 \\
(2.32-4.82) \\
\end{array}$ & $\begin{array}{c}4.14 \\
(3.44-5.27) \\
\end{array}$ & $\mathrm{p}=0.001$ \\
\hline Cholesterol (mg) & $\begin{array}{c}342.66 \\
(278.95-441.67)\end{array}$ & $\begin{array}{c}353.92 \\
(283.94-430.01)\end{array}$ & $\begin{array}{c}330.80 \\
(271.39-443.52)\end{array}$ & $\mathrm{p}=0.45$ \\
\hline
\end{tabular}

Results are presented as median (Q1-Q3). NLR - neutrophil to lymphocyte ratio; EPA - eicosapentaenoic acid, DHA docosahexaenoic acid. Mann-Whitney $\mathrm{U}$ test was used to assess the significance of differences. 

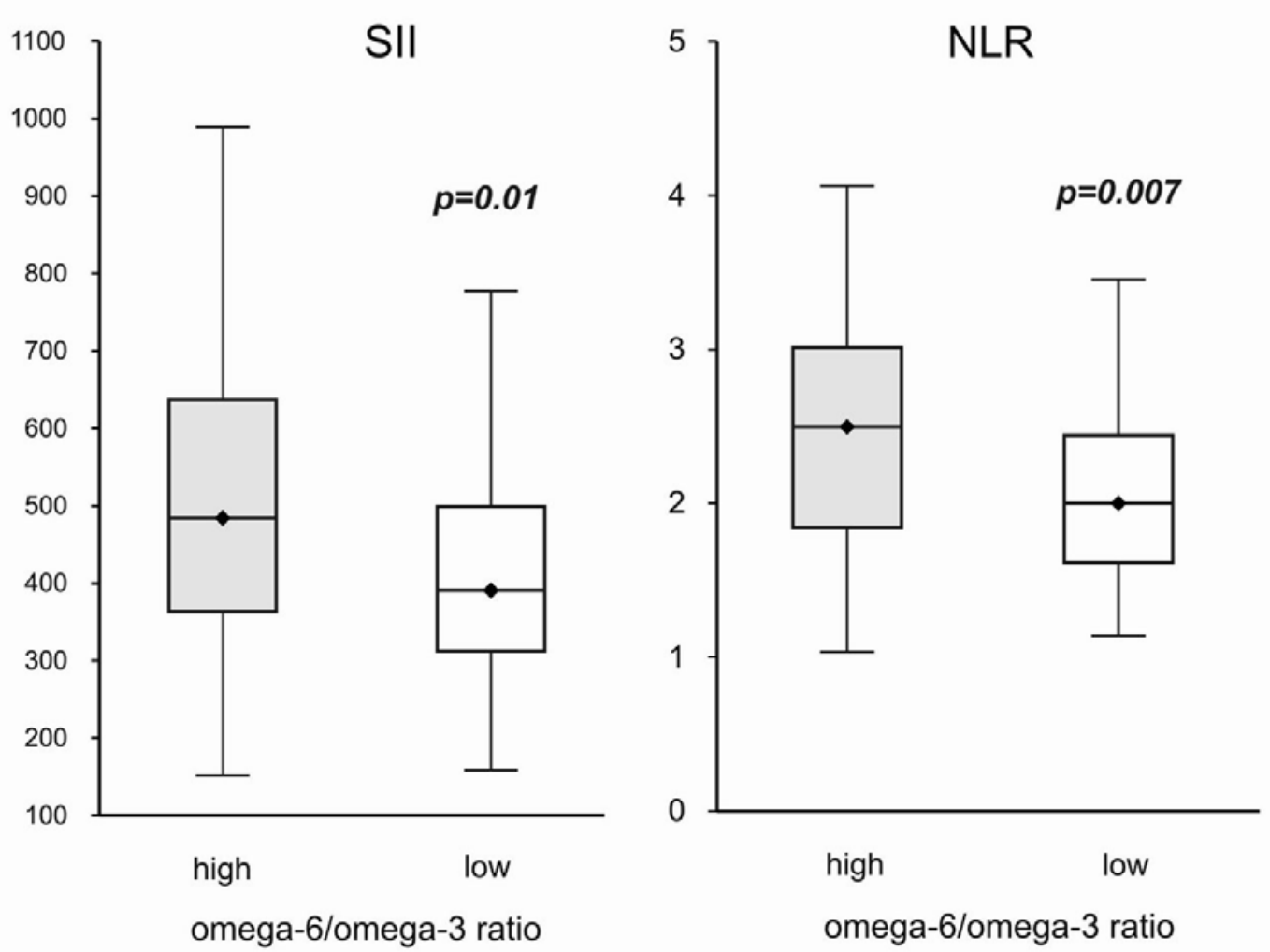

Figure 1. Levels of inflammatory markers (SII and NLR) in the groups with high and low ratio of omega-6 to omega-3 fatty acids. Results are presented as median (horizontal section), Q1-Q3 (bottom and top of the box), min and max values (whiskers). The Mann-Whitney $\mathrm{U}$ test was used to assess the significance of differences.

The differences were statistically significant for both SII and NLR values. Additionally, the NLR and SII inflammatory markers, are strongly and statistically significantly correlated with each other $(r=0.79$, $\mathrm{p}<0.001$ ).

Furthermore, the association between the ratio of omega-6 to omega-3 fatty acids and inflammatory markers was tested using Cohen's agreement test. Agreement was confirmed between the analysed variables. A significant association was found in two cases - between SII and the omega- 6 to omega-3 fatty acids ratio: agreement (\%) - 61.4, Cohen Kappa 0.23 (95\% CI 0.03-0.42, $\mathrm{p}=0.011)$ and between NLR and the omega-6 to omega-3 fatty acids ratio: agreement (\%) 65.4, Cohen Kappa 0.31 (95\% CI 0.11-0.50, p=0.001). Concordance between the omega- 6 to omega-3 fatty acids ratio and the inflammatory markers was in the poor to fair range, but reached a level of statistical significance.

\section{DISCUSSION}

There is an undeniable link between inflammation, diet, and cardiovascular disease. Plant polyphenols and omega-3 fatty acids are responsible to a large extent for a diet's cardioprotective effect $[9,16,33]$. With an anti-inflammatory diet, it is possible to reduce NLR values [25], which predict complications after cardiac surgery [31].

The aim of this study was to evaluate the nutrition of patients suffering from CAD, especially with regard to anti-inflammatory polyphenols and omega-3 fatty acids. Currently, a number of simple inflammatory markers are available, such as CRP (standard diagnostic marker detected in plasma) as well as SII and NLR (markers easily calculated from blood morphology) [1, 11, 32]. We hypothesized that patients that are following an anti-inflammatory diet may have reduced levels of inflammation markers before CABG.

A comparison of the intake of plant phenolic compounds with diet showed that the group with lower SII values was characterized by having a higher consumption of polyphenols, flavonoids, flavan-3ols, lower phenolic acids and lignans, and almost the same intake of stilbenes compared to the group with higher SII. Higher intakes of polyphenols, flavonoids, phenolic acids, and lignans, and a lower consumption of stilbenes were observed in the group with lower NLR compared to patients with higher NLR. The daily amount of flavan-3-ols was almost at the same level. However, these differences were not statistically significant.

The results of our previous study regarding CRP and NLR values were similar to those reported in the current study, despite differences in the severity 
of CAD. Also, the intake of omega-3 fatty acids was not significantly different [25]. Basing on our previous results, we left out the PLR (platelet to lymphocyte ratio) and MPVLR (mean platelet volume to lymphocyte ratio) parameters from the current study. Those markers' values were not related to the dietary intake of polyphenols or omega-3 fatty acids $[25,26]$. Interestingly, differences in CRP levels were observed between the total group of patients analysed in the current study, and a group of healthy volunteers (median [Q1-Q3] 1.7 [1.1-3.6] vs 1.0 [0.5-1.8]) [27].

Available publications mostly negate an association between the intake of omega-3 fatty acids and traditional inflammation markers $[15,30]$. No changes have been observed in the levels of inflammatory markers, such as hs-CRP, IL-6, and sICAM, between placebo and omega-3 supplementation groups [15]. A meta-analysis by Vors et al. has shown no difference in the effect of EPA or DHA supplementation on levels of inflammatory markers (such as CRP, IL6 , or TNF- $\alpha$ ) [30]. When analysing the nutritional intake of fatty acids, the group with lower levels of SII and NLR was characterized by lower intakes of saturated, monounsaturated and polyunsaturated fatty acids and omega- 6 to omega-3 fatty acids ratio, while having a higher intake of omega-3 fatty acids, EPA and DHA. This observation is difficult to discuss due to the limited literature on this subject [2]. The intake of omega-6 fatty acids in our study was practically the same in both subgroups with high and low values of SII, whereas the subgroup with a lower NLR had a lower daily intake of these fatty acids compared to the subgroup with a higher NLR. These differences were statistically significant only for the ratio of omega- 6 to omega- 3, EPA and DHA, and omega-3 fatty acids (when assessing the level of SII), therefore it is reasonable to assume that these compounds have the most important impact on the anti-inflammatory effect of patients' diets. This observation supports the findings of previous studies [25] and suggests also that the panel of markers should include a further inflammatory parameter, SII. In the context of the above-cited study describing the lack of effect of omega- 3 fatty acids consumption on CRP, IL- 6 and TNF- $\alpha$ levels $[15,30]$, our view is that the usefulness of the NLR and SII markers should be given due consideration.

Our study confirmed the role of the omega- 6 to omega-3 fatty acids ratio as a key parameter for assessing a patient's diet. Significant associations were found between SII and the omega-6 to omega-3 fatty acids ratio, as well as between NLR and the omega- 6 to omega-3 fatty acids ratio. Attention is increasingly being paid, not only to the ratio of omega- 6 to omega-3, but also to the quotient of EPA and arachidonic acid (AA), compared to the ratio of DHA to AA, in assessing possible adverse cardiovascular incidents. It has been reported that patients with one classical risk factor of CVD but a higher EPA to AA ratio were ultimately at a lower risk of CVD [18].

We found that levels of SII and NLR were significantly reduced in the subgroup of patients that had a lower ratio of omega-6 to omega-3 fatty acids. There are no published studies that estimate the effect of omega-3 fatty acids or plant polyphenols on SII levels. However, as our study has demonstrated, SII could be used as a predictor of a diet's anti- inflammatory effect. Interestingly, one recent published study has demonstrated that a modified diet has an effect on NLR in patients after surgery [19]. In our study, the group of patients with a higher omega- 6 to omega-3 ratio had an average NLR of 2.5. In the study by Sari et al., the NLR index reflected the severity of CAD in 180 patients after coronary angiography. An NLR level above 2.3 was a prognostic element for CAD [23]. In a study carried out by Yang et al. on 5,602 patients with CAD, the cut-off value of the SII index was $694.3 \times 10^{9} / \mathrm{L}$. It has been shown that a lower SII value was associated with a reduced risk of a nonfatal stroke or infarction, hospitalization due to heart failure or cardiac death [32].

Due to the lack of guidelines regarding standards for inflammatory markers, such as NLR and SII, Fest et al. [8] has proposed reference values for these parameters in the Rotterdam Study. That prospective cohort study included 8,711 individuals with a minimum age of 45 years, and the data was collected from 2002 to 2014. After calculating SII and NLR values based on blood count, the differences between levels were also considered according to age and gender. As presented in the results, the mean NLR and SII values calculated for patients participating in our study were 2.42 for NLR and 502.2 for SII. Whereas the reference values proposed by Fest et al. [8] for the 65-75 age group (the average age of patients in our study was $65.1 \pm 8.5$ years) were mean values of 1.82 for NLR and 455.0 for SII. This definitely shows that in our study both inflammatory markers were above the presented reference levels. Due to their simplicity and accessibility, these markers should be used as practical prognostic indicators to identify patients who are at high cardiac risk. Using SII and NLR for monitoring the anti-inflammatory effects of diet is a novel approach but is fully justified, in our opinion, in the light of recent findings. The our study's results support the proposal of Artiach et al., who suggested a need for further studies using novel methods that would more precisely identify the specific dietary predictors that influence inflammation in patients with CAD [2]. Our results are also in line with the developing trend of diet personalization $[6,14]$ and may enhance the panel of examinations allowing the better matching of 
diet to patient phenotype. In addition, a diet-mediated reduction of subthreshold clinical status in patients before CABG may contribute to an improved final outcome of surgical intervention $[5,12]$.

\section{CONCLUSIONS}

We conclude that there exists a need to assess a patient's nutritional habits, especially among cardiac patients. The level of NLR and SII can play an important role in patient supervision, reflecting the patient's diet while at the same time being an integral diagnostic element. The above-mentioned inflammatory markers can be an important tool in monitoring compliance with an anti-inflammatory diet. There is a need for precise reference values to be established for the NLR and SII indices in order to be able to correctly relate patient results to commonly accepted standards. The combined evaluation of nutritional and inflammatory marker levels can serve as a simple means of assessing the risk of adverse cardiovascular events following CABG. Early intervention, including modification of the diet, can significantly improve the health condition of patients. Non-pharmacological approaches, such as diet modifications, should be an auxiliary but integral part of the treatment of cardiac patients. We suggest also the consideration of a model in which a multidisciplinary team that includes a cardiologist/ cardiac surgeon, a dietitian, and a laboratory diagnostician, could work together to provide the most effective patient care.

\section{Conflict of interest}

The Authors declare no conflict of interest.

\section{REFERENCES}

1. Afari $M E$, Bhat $T$. Neutrophil to lymphocyte ratio (NLR) and cardiovascular diseases: an update. Expert Rev Cardiovasc Ther 2016; 14: 573-577 DOI: 10.1586/14779072.2016.1154788

2. Artiach $G$, Sarajlic $P$, Back $M$. Inflammation and its resolution in coronary artery disease: a tightrope walk between omega- 6 and omega-3 polyunsaturated fatty acids. Kardiol Pol 2020; 78: 93-95 DOI: 10.33963/ KP.15202

3. Bijak M, Sut A, Kosiorek A, Saluk-Bijak J, Golanski $J$. Dual Anticoagulant/Antiplatelet Activity of Polyphenolic Grape Seeds Extract. Nutrients 2019; 11: DOI: 10.3390/nu11010093

4. Boden S, Wennberg M, Van Guelpen B, Johansson $I$, Lindahl B, Andersson J, Shivappa N, Hebert JR, Nilsson LM. Dietary inflammatory index and risk of first myocardial infarction; a prospective populationbased study. Nutr J 2017; 16: 21 DOI: 10.1186/s12937017-0243-8
5. Dey S, Kashav R, Kohli JK, Magoon R, ItiShri, Walian $A$, Grover $V$. Systemic Immune-Inflammation Index Predicts Poor Outcome After Elective Off-Pump CABG: A Retrospective, Single-Center Study. J Cardiothorac Vasc Anesth 2020: DOI: 10.1053/j.jvca.2020.09.092

6. Di Renzo L, Cinelli G, Dri M, Gualtieri P, Attina $A$, Leggeri $C$, Cenname $G$, Esposito E, Pujia A, Chiricolo $G$, Salimei $C$, De Lorenzo A. Mediterranean Personalized Diet Combined with Physical Activity Therapy for the Prevention of Cardiovascular Diseases in Italian Women. Nutrients 2020; 12: DOI: 10.3390/ nu12113456

7. DiNicolantonio JJ, O'Keefe JH. Importance of maintaining a low omega-6/omega-3 ratio for reducing inflammation. Open Heart 2018; 5: e000946 DOI: 10.1136/openhrt-2018-000946

8. Fest J, Ruiter R, Ikram MA, Voortman T, van Eijck CHJ, Stricker BH. Reference values for white blood-cellbased inflammatory markers in the Rotterdam Study: a population-based prospective cohort study. Sci Rep 2018; 8: 10566 DOI: 10.1038/s41598-018-28646-w

9. Golanski J, Szymanska P, Rozalski M. Effects of Omega-3 Polyunsaturated Fatty Acids and Their Metabolites on Haemostasis-Current Perspectives in Cardiovascular Disease. Int J Mol Sci 2021; 22: DOI: 10.3390/ijms22052394

10. Golia E, Limongelli $G$, Natale F, Fimiani $F$, Maddaloni $V$, Pariggiano I, Bianchi $R$, Crisci M, D’Acierno L, Giordano R, Di Palma G, Conte M, Golino P, Russo MG, Calabro R, Calabro P. Inflammation and cardiovascular disease: from pathogenesis to therapeutic target. Curr Atheroscler Rep 2014; 16: 435 DOI: 10.1007/s11883014-0435-z

11. Gurbuz O, Kumtepe G, Ozkan H, Karal IH, Velioglu $Y$, Ercan A, Yuksel A, Ener $S$. Predictive Value of Neutrophil-Lymphocyte Ratio for Long-Term Cardiovascular Event Following Coronary Artery Bypass Grafting. Braz J Cardiovasc Surg 2020; 35: 274284 DOI: 10.21470/1678-9741-2018-0362

12. Haran C, Gimpel D, Clark H, McCormack DJ. Preoperative Neutrophil and Lymphocyte Ratio as a Predictor of Mortality and Morbidity After Cardiac Surgery. Heart Lung Circ 2021; 30: 414-418 DOI: 10.1016/j.hlc.2020.05.115

13. Haybar H, Pezeshki SMS, Saki N. Evaluation of complete blood count parameters in cardiovascular diseases: An early indicator of prognosis? Exp Mol Pathol 2019; 110: 104267 DOI: 10.1016/j.yexmp.2019.104267

14. Livingstone KM, Celis-Morales $C$, Navas-Carretero $S$, San-Cristobal R, Forster H, Woolhead C, O'Donovan $C B$, Moschonis G, Manios Y, Traczyk I, Gundersen TE, Drevon CA, Marsaux CFM, Fallaize R, Macready AL, Daniel H, Saris WHM, Lovegrove JA, Gibney M, Gibney ER, Walsh M, Brennan L, Martinez JA, Mathers JC. Characteristics of participants who benefit most from personalised nutrition: findings from the pan-European Food4Me randomised controlled trial. Br J Nutr 2020; 123: 1396-1405 DOI: 10.1017/S0007114520000653

15. Mackay I, Ford I, Thies F, Fielding S, Bachoo $P$, Brittenden $J$. Effect of Omega-3 fatty acid 
supplementation on markers of platelet and endothelial function in patients with peripheral arterial disease. Atherosclerosis 2012; 221: 514-520 DOI: 10.1016/j. atherosclerosis.2011.12.041

16. Massaro M, Scoditti E, Carluccio MA, De Caterina $R$. Nutraceuticals and prevention of atherosclerosis: focus on omega-3 polyunsaturated fatty acids and Mediterranean diet polyphenols. Cardiovasc Ther 2010; 28: e13-19 DOI: 10.1111/j.1755-5922.2010.00211.x

17. Mazidi M, Mikhailidis DP, Sattar N, Toth PP, Judd $S$, Blaha MJ, Hernandez AV, Penson PE, Banach M, International Lipid Expert P, Lipid, Blood Pressure Meta-analysis Collaboration $G$. Association of types of dietary fats and all-cause and cause-specific mortality: A prospective cohort study and meta-analysis of prospective studies with 1,164,029 participants. Clin Nutr 2020; 39: 3677-3686 DOI: 10.1016/j. clnu.2020.03.028

18. Nelson JR, Raskin S. The eicosapentaenoic acid:arachidonic acid ratio and its clinical utility in cardiovascular disease. Postgrad Med 2019; 131: 268277 DOI: 10.1080/00325481.2019.1607414

19. Ortiz-Reyes LA, Chang Y, Quraishi SA, Yu L, Kaafarani $H$, de Moya M, King DR, Fagenholz P, Velmahos $G$, Yeh $D D$. Early Enteral Nutrition Adequacy Mitigates the Neutrophil-Lymphocyte Ratio Improving Clinical Outcomes in Critically Ill Surgical Patients. Nutr Clin Pract 2019; 34: 148-155 DOI: 10.1002/ncp.10177

20. Pearson TA, Mensah GA, Alexander RW, Anderson JL, Cannon RO, 3rd, Criqui M, Fadl YY, Fortmann SP, Hong Y, Myers GL, Rifai N, Smith SC, Jr., Taubert K, Tracy RP, Vinicor F, Centers for Disease C, Prevention, American Heart A. Markers of inflammation and cardiovascular disease: application to clinical and public health practice: A statement for healthcare professionals from the Centers for Disease Control and Prevention and the American Heart Association. Circulation 2003; 107: 499-511 DOI: 10.1161/01.cir.0000052939.59093.45

21. Penson PE, Banach M. Natural compounds as antiatherogenic agents: Clinical evidence for improved cardiovascular outcomes. Atherosclerosis 2021; 316: 58-65 DOI: 10.1016/j.atherosclerosis.2020.11.015

22. Pimentel GD, Dela Vega MCM, Laviano A. High neutrophil to lymphocyte ratio as a prognostic marker in COVID-19 patients. Clin Nutr ESPEN 2020; 40: 101102 DOI: 10.1016/j.clnesp.2020.08.004

23. Sari I, Sunbul M, Mammadov C, Durmus E, Bozbay $M$, Kivrak $T$, Gerin F. Relation of neutrophil-tolymphocyte and platelet-to-lymphocyte ratio with coronary artery disease severity in patients undergoing coronary angiography. Kardiol Pol 2015; 73: 1310-1316 DOI: $10.5603 /$ KP.a2015.0098

24. Shrivastava AK, Singh $H V$, Raizada A, Singh SK. C-reactive protein, inflammation and coronary heart disease. The Egyptian Heart Journal 2015; 67: 89-97
25. Sut A, Chizynski K, Rozalski M, Golanski J. Dietary intake of omega fatty acids and polyphenols and its relationship with the levels of inflammatory markers in men with chronic coronary syndrome after percutaneous coronary intervention. Kardiol Pol 2020; 78: 117-123 DOI: $10.33963 / \mathrm{kp} .15078$

26. Sut A, Pytel M, Zadrozny M, Golanski J, Rozalski M. Polyphenol-rich diet is associated with decreased level of inflammatory biomarkers in breast cancer patients. Rocz Panstw Zakl Hig 2019; 70: 177-184

27. Szymanska P, Boncler M, Golanski J. Cellular and biochemical predictors of high platelet reactivity assessed by Multiple Electrode Aggregometry (MEA) in healthy individuals. Diagn Lab 2021; in press:

28. Tamtaji OR, Milajerdi A, Reiner Z, Dadgostar E, Amirani E, Asemi Z, Mirsafaei L, Mansournia MA, Dana PM, Sadoughi F, Hallajzadeh J. Effects of flaxseed oil supplementation on biomarkers of inflammation and oxidative stress in patients with metabolic syndrome and related disorders: A systematic review and meta-analysis of randomized controlled trials. Clin Nutr ESPEN 2020; 40: 27-33 DOI: 10.1016/j.clnesp.2020.09.017

29. Ustundag $Y$. Relationship between CRP, systemic immune-inflammation index and routine hemogram related inflammatory markers in low grade inflammation. International Journal of Medical Biochemistry 2018: DOI: $10.14744 / \mathrm{ijmb} .2017 .08108$

30. Vors C, Allaire J, Mejia SB, Khan TA, Sievenpiper JL, Lamarche B. Comparing the Effects of Docosahexaenoic and Eicosapentaenoic Acids on Inflammation Markers Using Pairwise and Network Meta-Analyses of Randomized Controlled Trials. Adv Nutr 2021; 12: 128140 DOI: 10.1093/advances/nmaa086

31. Weedle RC, Da Costa M, Veerasingam D, Soo AWS. The use of neutrophil lymphocyte ratio to predict complications post cardiac surgery. Ann Transl Med 2019; 7: 778 DOI: 10.21037/atm.2019.11.17

32. Yang YL, Wu CH, Hsu PF, Chen SC, Huang SS, Chan WL, Lin SJ, Chou CY, Chen JW, Pan JP, Charng MJ, Chen YH, Wu TC, Lu TM, Huang PH, Cheng HM, Huang CC, Sung SH, Lin YJ, Leu HB. Systemic immuneinflammation index (SII) predicted clinical outcome in patients with coronary artery disease. Eur J Clin Invest 2020; 50: e13230 DOI: 10.1111/eci.13230

33. Zampelas A, Magriplis E. Dietary patterns and risk of cardiovascular diseases: A review of the evidence. Proceedings of the Nutrition Society 2020; 79: 68-75

Received: 02.06.2021

Accepted: 07.07.2021

Published online first: 12.07 .2021 